DOI 10.15290/cnisk.2021.02.11.10

\author{
DIANA DAJNOWICZ-PIESIECKA \\ https://orcid.org/0000-0003-1609-8463 \\ Wydział Prawa Uniwersytetu w Białymstoku
}

\title{
Rodzina w świetle wybranych aktów prawnych z okresu Polski Ludowej ${ }^{1}$
}

\begin{abstract}
Streszczenie
Rodzina była istotna składową społeczeństwa w okresie Polski Ludowej, ponieważ miała swój udział w zaspokajaniu ideologiczno-politycznych potrzeb państwa poprzez dostarczanie nowych budowniczych socjalizmu. Majac na uwadze znaczenie rodziny, zarówno to historyczne, jak i współczesne, w niniejszym artykule przedstawiono i omówiono wybrane akty prawne uchwalone w okresie Polski Ludowej, które obejmowały ochrona podstawowa komórkę społeczna, jaka jest rodzina. Na podstawie omówienia postanowień Konstytucji Polskiej Rzeczypospolitej Ludowej z 1952 r., kodeksu rodzinnego z 1950 r., kodeksu rodzinnego i opiekuńczego z 1969 r., kodeksu karnego z 1969 r. oraz ustawy o funduszu alimentacyjnym z 1974 r. ukazano, w jakim zakresie rodzina pozostawała w latach 1944-1989 w zainteresowaniu ustawodawcy.

Słowa kluczowe: rodzina, ochrona rodziny, Polska Ludowa, Konstytucja PRL, prawo rodzinne, prawo karne

\footnotetext{
Publikacja przygotowana/finansowana w ramach programu Ministra Nauki i Szkolnictwa Wyższego pod nazwą DIALOG w latach 2019-2021. Jest wynikiem udziału w projekcie badawczym pt. „Ośrodek badań historii kobiet”, nr 0016/DLG/2019/10.
} 


\title{
THE FAMILY IN THE LIGHT OF SELECTED LEGAL ACTS FROM THE PERIOD OF THE PEOPLE'S REPUBLIC OF POLAND
}

\begin{abstract}
The family was an important component of society in the period of the People's Republic of Poland because it had its share in meeting the ideological and political needs of the state by providing new builders of socialism. Bearing in mind the importance of the family, both historical and contemporary, this article presents and discusses selected legal acts enacted in the period of the People's Republic of Poland, which protected the basic social cell, the family. Based on the discussion of the provisions of the Constitution of the People's Republic of Poland of 1952, the Family Code of 1950, the Family and Guardianship Code of 1969, the Penal Code of 1969 and the Alimony Fund Act of 1974, it is shown to what extent the family remained in the interest of the legislature in the years 1944-1989.

Keywords: family, family protection, People's Poland, Constitution of the People's Republic of Poland, family law, criminal law

Rodzina była istotną składową społeczeństwa w okresie Polski Ludowej, ponieważ miała swój udział w zaspokajaniu ideologiczno-politycznych potrzeb państwa poprzez dostarczanie nowych budowniczych socjalizmu, dbanie o nich i zapewnianie odpowiedniej opieki i wychowania zgodnego $z$ ówczesnymi nastrojami politycznymi $^{2}$. W związku $z$ wyzwaniami, jakie państwo stawiało $\mathrm{w}$ tamtym czasie przed rodzina, za niezbędne uznano zabezpieczanie jej dobra na gruncie aktów prawa. Mimo że polityka ustawodawcza tamtego okresu była zorientowana przede wszystkim na sprostanie potrzebom politycznym państwa i służyła partii do regulowania relacji $z$ obywatelami ${ }^{3}$, w jej ramach opieką obejmowano również rodzinę, co stanowiło wyraz świadomości ówczesnej władzy w zakresie znaczenia (politycznego i społecznego) podstawowej grupy tworzonej przez spokrewnione ze sobą osoby.

Mając na uwadze hierarchię źródeł prawa, rozważania dotyczace rodziny w ustawodawstwie okresu Polski Ludowej wypada rozpocząć od Konstytucji Polskiej Rzeczypospolitej Ludowej z 1952 r.,

\footnotetext{
2 Renata Doniec, „Oblicza codzienności a kondycja psychospołeczna rodziny w czasach socjalizmu realnego w Polsce", w: Barbara Kiereś, Monika Gromek, Katarzyna Hryszan (red.), Rodzina - historia i współczesność, (Lublin: Wydawnictwo Episteme, 2018), 48.

3 Adam Łopatka, „Ogólne założenia polityki legislacyjnej PRL”, Państwo i Prawo, z. 1(311), 1972, 5.
} 
potocznie nazywanej konstytucja stalinowska, a także konstytucja lipcowa ${ }^{4}$. Konstytucja PRL została jednomyślnie uchwalona przez Sejm Ustawodawczy 22 lipca 1952 r., kończąc w ten sposób trwający od 1944 r. stan prowizorium konstytucyjnego. $Z$ dniem 31 grudnia 1989 r. zmieniono ją w Konstytucję Rzeczypospolitej Polskiej, która została ostatecznie uchylona 17 października 1997 r. Projektodawcy tego najważniejszego aktu prawnego $z$ okresu powojennego wzorowali się na Konstytucji Związku Sowieckiego z 1936 r., co było niebudzącą wątpliwości zapowiedzią przyszłych kierunków rozwoju Polski ${ }^{5}$. Konstytucja miała charakter deklaratywno-propagandowy, co się przejawiało chociażby w ograniczonym, wręcz przesadnie skromnym, odniesieniu do znaczenia i roli Polskiej Zjednoczonej Partii Robotniczej, wskazując jedynie, że jest ona przewodnią siła polityczną społeczeństwa w budowie socjalizmu (art. 3).

Pierwotna wersja Konstytucji PRL wspominała o rodzinie tylko w jednym miejscu, a mianowicie w art. 67, który stanowił, że małżeństwo oraz rodzina znajduja się pod opieka i ochrona Polskiej Rzeczypospolitej Ludowej, a rodziny wielodzietne państwo otacza szczególną troską ${ }^{6}$. Można więc dostrzec, zwłaszcza porównując ze współcześnie obowiązującą ustawą zasadniczą ${ }^{7}$ że rodzina nie była szeroko zabezpieczana $\mathrm{w}$ poczatkowej działalności ustawodawczej Polski Ludowej. Przyjęta w 1952 r. wersja Konstytucji PRL przekonuje, że w tamtym okresie nie dostrzegano potrzeby szerokiego zabezpieczania rodziny, ograniczając się do pojedynczych, dość powierzchownych $\mathrm{w}$ tym zakresie postanowien. Taka postawa prawodawcy nie powinna jednak dziwić, ponieważ prawna opieka nad rodzina rozwijała się na przestrzeni wielu dziesięcioleci, a w połowie ubiegłego wieku była zaledwie na etapie powolnego wykluwania się $z$ powstajacych wówczas aktów prawnych.

\footnotetext{
4 Konstytucja Polskiej Rzeczypospolitej Ludowej uchwalona przez Sejm Ustawodawczy w dniu 22 lipca 1952 r., (Dz.U. z 1976 r. Nr 7, poz. 36 ze zmianami wniesionymi do 30 grudnia 1989 r.).

5 Dariusz Makiłła, Historia prawa w Polsce, (Warszawa: PWN, 2008), 561-562.

6 Konstytucja Polskiej Rzeczypospolitej Ludowej uchwalona przez Sejm Ustawodawczy w dniu 22 lipca 1952 r., (Dz.U. 1952 r. Nr 33, poz. 232).

$7 \quad$ Konstytucja Rzeczypospolitej Polskiej z dnia 2 kwietnia 1997 r., (Dz.U. Nr 78, poz. 483 ze zm.) używa pojęcia rodziny w preambule, art. 18 określającym zasadę opieki państwa nad małżeństwem i rodziną, art. 23 wskazującym, iż gospodarstwo rodzinne stanowi podstawę ustroju rolnego, art. 33 precyzującym zasadę równouprawnienia płci, art. 41 określającym gwarancję nietykalności i wolności osobistej, art. 47 dotyczącym zasady ochrony życia prywatnego oraz w art. 71 określającym prawo rodziny do szczególnej pomocy państwa.
} 
Konstytucja PRL podczas 45 lat obowiązywania była aż 24 razy nowelizowana. Szczególnie obszerne zmiany dotyczące rodziny zostały wprowadzone do Konstytucji nowelizacją z 1976 r. ${ }^{8}$, wskutek której ochroną objęto znacznie szerszy zakres zagadnień dotyczących rodziny $\mathrm{w}$ porównaniu $\mathrm{z}$ problematyką uregulowana $\mathrm{w}$ dawnym brzmieniu tego aktu prawnego ${ }^{9}$.

Społeczna waga rodziny została wyjątkowo mocno uwydatniona w nowelizacji Konstytucji z 1976 r., przez co jej ranga w oficjalnie uznanym systemie preferencji dóbr istotnie wzrosła. Rodzina stała się więc dobrem wysoko cenionym w Polsce Ludowej, co znalazło swoje odzwierciedlenie już w przepisach początkowych Konstytucji, a mianowicie w art. 5, który określał podstawowe funkcje Polskiej Rzeczypospolitej Ludowej ${ }^{10}$.

W znowelizowanej Konstytucji PRL po raz pierwszy wspomniano o rodzinie w art. 5, w którym wskazano, że Polska Rzeczpospolita Ludowa „w trosce o rozwój narodu otacza opieka rodzinę, macierzyństwo i wychowanie młodego pokolenia”. Tym samym nadano rodzinie specjalną rangę wśród całokształtu dóbr społecznie i państwowo doniosłych, czyniąc $z$ rodziny przedmiot reguły konstytucyjnej. Ochrona rodziny została ujęta w rozdziale pierwszym Konstytucji zatytułowanym „Ustrój polityczny”, więc uczyniono $z$ niej jedno $z$ najważniejszych, naczelnych zadań państwa oraz sprawujacych władzę. Co istotne, ujęta w Konstytucji z 1952 r. zasada ochrony rodziny stanowiła treściowy pierwowzór współczesnej formuly art. 18 Konstytucji RP z 1997 r., w którym również ochroną objęto rodzinę, a także małżeństwo, macierzyństwo i rodzicielstwo ${ }^{11}$.

W art. 79 ust. 1 Konstytucji PRL dokonano pogłębienia ochrony rodziny poprzez określenie zasady ochrony małżeństwa i rodziny. W wymienionym przepisie prawodawca zadeklarował, iż małżeństwo, macierzyństwo i rodzina znajduja się pod opieka i ochroną Polskiej Rzeczypospolitej Ludowej. Dodano także, że

\footnotetext{
8 Ustawa z dnia 10 lutego 1976 r. o zmianie Konstytucji Polskiej Rzeczypospolitej Ludowej, (Dz.U. 1976 Nr 5, poz. 29).

9 Zbigniew Radwański, „Zmiany konstytucyjne PRL dotyczace rodziny”, Ruch Prawniczy, Ekonomiczny i Socjologiczny, z. 2, 1977, 1.

10 Ibidem.

11 Leszek Garlicki, „Komentarz do art. 18 Konstytucji RP”, w: Leszek Garlicki, Marek Zubik (red.), Konstytucja Rzeczypospolitej Polskiej. Komentarz, t. 1, (Warszawa: Wydawnictwo Sejmowe, 2016), baza prawnicza LEX.
} 
szczególną troską państwo otacza rodziny o licznym potomstwie. W dalszych ustępach art. 79 Konstytucji rozwinięto zasadę ochrony rodziny, macierzyństwa i małżeństwa, wskazując, że:

- do obowiązków rodziców należy wychowywanie dzieci na prawych i świadomych swoich obowiąków obywateli Polskiej Rzeczypospolitej Ludowej (ust. 2),

- Polska Rzeczpospolita Ludowa zapewnia realizacje praw i obowiązków alimentacyjnych (ust. 3),

- zarówno dzieci urodzone w małżeństwie, jak i poza małżeństwem mają te same prawa (ust. 4),

- $\quad$ z uwagi na troskę o dobro rodziny Polska Rzeczpospolita Ludowa podejmuje działania na rzecz poprawy sytuacji mieszkaniowej, zaś przy współudziale obywateli rozwija i popiera budownictwo mieszkaniowe (zwłaszcza budownictwo spółdzielcze), dba o racjonalna gospodarkę zasobami mieszkaniowymi (ust. 5).

Określona w art. 79 ust. 1 Konstytucji PRL zasada ochrony małżństwa i rodziny zobowiazywała instytucje państwa, by w swoich decyzjach uwzględniały dobro rodziny i małżeństwa i podejmowały działania sprzyjające umacnianiu więzi rodzinnych i relacji między spokrewnionymi ze soba osobami. Przykład realizacji przedmiotowej zasady przedstawił w swoim orzeczeniu Sad Najwyższy, w którego ocenie wynika $z$ niej obowiązek sądów szczególnie starannego i wnikliwego orzekania w sprawach rozwodowych. Wskazano przy tym, że „prawidłowe orzecznictwo w tych sprawach, realizujące ściśle przepisy postępowania prawa socjalistycznego, stanowi pozytywny czynnik, wychowujący obywateli w duchu poszanowania rodziny jako podstawowej komórki społecznej"12. Tym samym Sąd Najwyższy w swojej uchwale wyraził konieczność kształtowania przez sądy orzekające w sprawach o rozwód właściwych poglądów moralnych obywateli w zakresie ich stosunków małżeńskich. Dodatkowo wskazał, że „gdy w małżeństwie sa małoletnie dzieci, prawidłowe rozstrzygnięcie sprawy o rozwód wymaga szczegółowego rozważenia, czy na skutek rozwodu dobro dzieci nie ucierpi. Jeśli okoliczności sprawy wniosek taki usprawiedliwiaja, rozwód nie jest dopuszczalny".

12 Uchwała Sądu Najwyższego z dnia 28 maja 1955 r., sygn. I CO 5/55, OSNCK 1955, nr 3, poz. 46. 
Przytoczone orzeczenie obrazuje, jak realizowano zasadę ochrony rodziny, stawiajac jej trwałość ponad dobro jednostki, bowiem gdyby w ocenie sądu rozwód wywarł negatywny wpływ na życie dziecka, zgodnie $z$ nakazem Sądu Najwyższego powództwo o rozwód należało oddalić. Uchwała ta doskonale pokazuje mechanizm działania ówczesnego wymiaru sprawiedliwości - na porządku dziennym było formułowanie przez Sąd Najwyższy wytycznych dla sądów powszechnych w zakresie tego, co powinny orzekać oraz jakie okoliczności brać, a jakich nie brać pod uwagę, dokonujacc oceny stanu faktycznego danej sprawy. Formułowanie przez poddawany politycznej presji Sąd Najwyższy wytycznych orzeczniczych dla sądów było charakterystyczne dla okresu Polski Ludowej i występowało nie tylko w sprawach rodzinnych, lecz również cywilnych czy karnych.

Wprowadzenie w 1976 r. do Konstytucji PRL z 1952 r. tak licznych odniesień do ochrony przez państwo oraz społeczeństwo rodziny było wyrazem uznania jej wysokiej rangi w ówczesnym ustroju społeczno-politycznym. Przeorientowanie zadań Polskiej Rzeczypospolitej Ludowej w zakresie opieki nad rodzina poniekąd spowodowane było debata dotycząca tego zagadnienia prowadzona na arenie międzynarodowej. Prowadzono ja przede wszystkim na gruncie dokumentów przyjmowanych przez Zgromadzenie Ogólne ONZ, a w szczególności w przyjętych 16 lipca 1966 r. przez Zgromadzenie Ogólne ONZ Pakcie praw obywatelskich i politycznych ${ }^{13}$ oraz Pakcie praw gospodarczych i kulturalnych ${ }^{14}$, które formułowały np. zasadę poszanowania wolności rodziców lub opiekunów do zapewnienia swym dzieciom wychowania religijnego i moralnego zgodnie $z$ ich własnymi przekonaniami, zasadę ochrony dzieci ze strony rodziny, społeczeństwa i państwa, a także zasadę ochrony macierzyństwa ${ }^{15}$.

Również program społeczno-gospodarczy Polskiej Zjednoczonej Partii Robotniczej wpłynał na wprowadzone w 1976 r. zmiany w Konstytucji. Kwestiom rodziny ze szczególną uwaga zaczęto się przyglądać zwłaszcza w latach 70 . XX w., gdy inicjowano szereg przedsięwzięć socjalnych na rzecz rodziny, w tym m.in. przedłużono płatne urlopy macierzyńskie, ustanowiono państwowy fundusz

\footnotetext{
13 Międzynarodowy Pakt Praw Obywatelskich i Politycznych otwarty do podpisu w Nowym Jorku dnia 19 grudnia 1966 r., (Dz.U. 1977 Nr 38, poz. 167).

14 Międzynarodowy Pakt Praw Gospodarczych, Społecznych i Kulturalnych otwarty do podpisu w Nowym Jorku dnia 19 grudnia 1966 r., (Dz.U. 1977 Nr 38, poz. 169).

15 Zbigniew Radwański, „Zmiany konstytucyjne PRL dotyczące rodziny”, 2-3.
} 
alimentacyjny, a także zwiększono dodatki rodzinne i zintensyfikowano budownictwo mieszkaniowe. Natomiast formalnym ucieleśnieniem uznawania rodziny za istotny element porządku socjalistycznego było rozszerzenie Statutu PZPR o nakaz dla członków partii, by ci rzetelnie wypełniali swoje obowiązki wobec rodziny oraz brali odpowiedzialność za socjalistyczne wychowanie dzieci. Przedstawione zmiany i regulacje utwierdzają w przekonaniu, że na kanwie Konstytucji PRL chciano włączyć rodzinę do budowania siły politycznej PRL oraz nurtu ideologicznego tamtego okresu ${ }^{16}$.

Niezwykle ważnymi aktami prawnymi okresu Polski Ludowej odnoszącymi się do rodziny były kodeks rodzinny z 1950 r. ${ }^{17}$ oraz zastępujący go kilkanaście lat później kodeks rodzinny i opiekuńczy z 1964 r. ${ }^{18}$ Kodeks rodzinny z 1950 r. był pierwszym kodeksem Polski Ludowej. Składał się on z 93 artykułów uporządkowanych w czterech tytułach, które dzieliły się na działy. Zawarte w kodeksie tytuły dotyczyły: małżeństwa (na gruncie tej grupy przepisów uregulowano kwestie zawarcia małżeństwa, praw i obowiązków małżonków oraz rozwodów), rodziców i dzieci (w tytule tym zawarto przepisy ogólne oraz regulacje dotyczace ustalenia ojcostwa, władzy rodzicielskiej, przysposobienia i obowiazku alimentacyjnego), opieki nad małoletnimi oraz przepisów końcowych. Kodeks ten miał jednak wiele luk, co doprowadziło do sytuacji nietypowej dla prawa kontynentalnego. W zwiazku $z$ tym, że kodeks nie regulował bądź regulował w ograniczonym zakresie pewne sfery spraw rodzinnych (np. pomijał zagadnienie ustalenia i zaprzeczenia macierzyństwa), kluczowa role odgrywały sądy i ich interpretacja istniejących przepisów ${ }^{19}$. Sytuacja ta doprowadziła do konieczności podjęcia działań na rzecz stworzenia nowego zbioru przepisów prawa rodzinnego, czego efektem było uchwalenie w 1964 r. ustawy - Kodeks rodzinny i opiekuńczy.

Nowy kodeks rodzinny i opiekuńczy został znacząco rozbudowany w porównaniu $z$ kodeksem rodzinnym z $1950 \mathrm{r}$. Zwiększono w nim liczbę artykułów do 184, zmieniono zakres kodeksu, ujmując w nim uregulowania dotyczace opieki i kurateli, poprawiono i uporządkowano jego układ, a także usunięto lub przekonstruowano

\footnotetext{
16 Ibidem, 3-4.

17 Ustawa z dnia 27 czerwca 1950 r. - Kodeks rodzinny, (Dz.U. 1950 Nr 34, poz. 308).

18 Ustawa z dnia 25 lutego 1964 r. - Kodeks rodzinny i opiekuńczy, (Dz.U. 1964 Nr 9, poz. 59).

19 Piotr Fiedorczyk, Unifikacja i kodyfikacja prawa rodzinnego w Polsce (1945-1964), (Białystok: Wydawnictwo Uniwersytetu w Białymstoku, 2014), 282.
} 
użyte wcześniej, często nieprecyzyjne i niezrozumiałe sformułowania. Do rozwiązań szczególnie ulepszających ówczesny stan prawny zaliczono przepisy dotyczące stosunków majątkowych między małżonkami, relacji majątkowych między rodzicami a dziećmi oraz między opiekunem a podopiecznym, jak również zmiany w przepisach rozwodowych, alimentacyjnych oraz o przysposobieniu ${ }^{20}$.

Innym aktem prawnym, który traktował o rodzinie jak o dobru wymagajacym ochrony, był kodeks karny z 1969 r. ${ }^{21}$ nazywany potocznie kodeksem Andrejewa (od nazwiska prof. Igora Andrejewa - głównego twórcy projektu kodeksu). Kodeks z 1969 r. zastapił kodeks karny z $1932 \mathrm{r}^{22}$, przyjmując w nim odmienna systematykę przestępstw, co wynikało przede wszystkim $z$ przewartościowania życia społeczno-politycznego przez sprawujacych wtedy władzę ${ }^{23}$.

Mając na uwadze tendencje ustawodawcze państw trzecich dotyczace kształtowania prawa karnego, ustawodawca zdecydował się umieścić w kodeksie karnym z 1969 r. odrębny rozdział poświęcony wyłącznie prawnokarnej ochronie rodziny, w którym sprecyzował katalog przestępstw przeciwko rodzinie ${ }^{24}$. Rozwiązanie takie było swoistym novum, bowiem wcześniej obowiąujący kodeks karny nie zawierał takiej systematyki przestępstw, a przepisy tyczące się rodziny były rozlokowane w różnych częściach aktu prawnego.

Katalog przestępstw przeciwko rodzinie umiejscowiony został w kodeksie karnym z 1969 r. w rozdziale XXV, gdzie określono występki: bigamię, znęcanie się, rozpijanie małoletniego, niealimentację, porzucenie dziecka lub osoby nieporadnej oraz uprowadzenie lub zatrzymanie małoletniego lub osoby nieporadnej.

Bigamia (inaczej dwużeństwo) była pierwszym z przestępstw przeciwko rodzinie, które ustawodawca ujął w rozdziale XXV kodeksu z 1969 r. Występek ten określono w art. 183 § 1 k.k. z 1969 r., w którym wskazano, że osoba, która zawiera małżeństwo mimo pozostawania już w związku małżeńskim, podlega karze pozbawienia wolności od 6 miesięcy do lat 5 . Co ciekawe, taką samą karę prze-

\footnotetext{
20 Ibidem, 734-736.

21 Ustawa z dnia 19 kwietnia 1969 r. - Kodeks karny, (Dz.U. 1969 r. Nr 13, poz. 94).

22 Rozporządzenie Prezydenta Rzeczypospolitej z dnia 11 lipca 1932 r. - Kodeks karny, (Dz.U. z 1932 r. Nr 60, poz. 571).

23 Diana Dajnowicz-Piesiecka, Przestepczość godzaca $w$ rodzine. Studium prawno-kryminologiczne, (Białystok: Temida2, 2020), 45.

24 Jerzy Bafia, Kryspin Mioduski, Mieczysław Siewierski, Kodeks karny. Komentarz, (Warszawa: Wydawnictwo Prawnicze, 1987), 171-172.
} 
widziano wobec osoby, która zawiera małżeństwo $z$ osoba pozostająca już w związku małżeńskim (stanowił o tym § 2).

Drugim przestępstwem $z$ rodzaju przeciwko rodzinie było określone w art. 184 k.k. z 1969 r. znęcanie się nad rodziną. We wskazanym przepisie przyjęto, że osoba, która znęca się fizycznie lub moralnie nad członkiem swojej rodziny lub inną osoba pozostająca w stałym lub przemijającym stosunku zależności od sprawcy albo nad małoletnim lub osoba bezradna, podlega karze pozbawienia wolności od 6 miesięcy do lat 5 (§ 1). Przewidziano również typ kwalifikowany znęcania się i dotyczył on takiego znęcania się, którego następstwem było targnięcie się pokrzywdzonego na własne życie (§ 2) - wówczas sprawca przestępstwa podlegał surowszej karze, a mianowicie groziło mu pozbawienie wolności do 10 lat.

Wśród przestępstw przeciwko rodzinie określono także rozpijanie małoletniego. Występek ten ujęto w art. 185 k.k. z 1969 r., wskazując, że osoba, która dostarcza małoletniemu napojów alkoholowych, ułatwia mu ich spożycie lub nakłania do ich spożywania podlega karze pozbawienia wolności do lat 3 .

Kolejnym istotnym przestępstwem godzącym w dobro rodziny było określone w art. 186 k.k. z 1969 r. niedopełnienie obowiązku alimentacyjnego. Przestępstwo niealimentacji polegało na uporczywym uchylaniu się od wykonania ciążącego na danej osobie z mocy ustawy obowiazku łożenia na utrzymanie dziecka, rodziców lub innej osoby najbliższej, narażając ją w ten sposób na niemożność zaspokojenia podstawowych potrzeb życiowych. Za to przestępstwo określono karę pozbawienia wolności do lat 3 .

W rozdziale przestępstw przeciwko rodzinie określono również porzucenia - stanowił o nim art. 187 k.k. z 1969 r. Występek ten polegał na porzuceniu, pozostawieniu samej sobie, wbrew obowiazkowi troszczenia się, osoby poniżej 15 roku życia badź nieporadnej ze względu na stan psychiczny lub fizyczny. Ustawodawca wskazał, że za popełnienie tego przestępstwa sprawca może ponieść karę pozbawienia wolności od 6 miesięcy do lat 5 .

Ostatnim przestępstwem zaliczonym w kodeksie karnym z 1969 r. do katalogu przestępstw przeciwko rodzinie było określone w art. 188 k.k. z 1969 r. porwanie małoletniego lub osoby nieporadnej. Przedmiotowy występek polegał na uprowadzeniu lub zatrzymaniu małoletniego lub osoby nieporadnej ze względu na jej stan fizyczny lub psychiczny wbrew woli powołanego do opieki lub 
nadzoru. Za popełnienie tego przestępstwa sprawcy groziła kara pozbawienia wolności od 6 miesięcy do 5 lat.

Wśród przestępstw przeciwko rodzinie jednym $z$ najczęściej popełnianych była niealimentacja. Co ciekawe, ten stan rzeczy nie zmienił się na przestrzeni lat i współcześnie również przestępstwo niealimentacji należy do najbardziej pospolitych przestępstw przeciwko rodzinie. Taka tendencja $\mathrm{w}$ rozmiarach i strukturze przestępczości była i wciąz pozostaje smutnym odzwierciedleniem tych obszarów życia rodzinnego, które od dziesięcioleci wymaga istotnej pomocy ze strony organów ścigania, wymiaru sprawiedliwości i innych organów państwowych.

Głównym aktem prawnym, który od lat 60 . XX w. po współczesność reguluje kwestię dotycząca alimentów, jest wspomniany $\mathrm{w}$ poprzednich akapitach kodeks rodzinny i opiekuńczy. Należy jednak zwrócić uwagę także na ustawę o funduszu alimentacyjnym z $1974 \mathrm{r}^{25}$, która miała na celu poprawę funkcjonowania w praktyce sądowej instytucji obowiązku alimentacyjnego oraz obowiązku przyczyniania się do zaspokajania potrzeb rodziny.

Przedmiotowa ustawa wprowadzała w obszarze zaspokajania potrzeb rodziny rozwiązania dotą nieznane prawu Polski Ludowej. Ustawa pozwalała uprawnionym uzyskać odpowiednie środki na utrzymanie w przypadku problemów $z$ wyegzekwowaniem ich od dłużnika alimentacyjnego. Instytucja ta ułatwiała dochodzenie świadczeń alimentacyjnych, przyczyniając się w ten sposób do poprawy sytuacji życiowej osób uprawnionych do alimentów. Co ważne, w art. 1 ustawy wprost wskazano, że fundusz przeznaczony jest przede wszystkim na wypłatę świadczeń pieniężnych dla dzieci. Wskazuje się, że jego utworzenie przede wszystkim zmierzać miało do zadbania o prawidłowy rozwój dzieci i młodzieży $z$ rozbitych rodzin ${ }^{26}$. W ten sposób ustawa udzielała wsparcia przede wszystkim kobietom - matkom, które nie mogły wyegzekwować od ojców swoich dzieci należnych im alimentów.

Przedstawione wyżej wybrane akty prawne $z$ okresu Polski Ludowej obejmujące ochroną rodzinę zarysowuja, w jakim obszarze ta podstawowa komórka społeczna pozostawała w latach 1944-1989 w zainteresowaniu ustawodawcy. Na podstawie ledwie szkicu, bo opracowanie to nie pretenduje do miana całościowego

\footnotetext{
25 Ustawa $z$ dnia 18 lipca 1974 r. o funduszu alimentacyjnym, (Dz.U. 1974 Nr 27, poz. 157).

26 Andrzej Murzynowski, „Nałożenie obowiązku naprawienia skutków przestępstwa jako element nowej polityki karania", Państwo i Prawo, nr 5, 1970, 714.
} 
ujęcia przedmiotowego zagadnienia, dostrzec można, że dopiero po kilkunastu (a nawet kilkudziesięciu) latach istnienia Polski Ludowej rodzina zaczęła być postrzegana jako istotny element systemu wymagajacy opieki i ochrony ze strony państwa i społeczeństwa. W pierwszych latach aktów prawnych regulujących sferę spraw rodzinnych nie było wiele, choć na uwagę zasługuje fakt, że pierwszym kodeksem przyjętym w Polsce Ludowej był właśnie kodeks rodzinny, który jednak charakteryzowała próżnia prawna w wielu obszarach spraw dla rodziny istotnych. Na przestrzeni lat obserwowany był rozwój ustawodawstwa omawianego rodzaju, stanowiący być może przejaw pogłębiającej się troski o instytucję rodziny, a niewatpliwie wzrost świadomości, że kondycja każdego społeczeństwa uzależniona jest od kondycji podstawowych grup budujacych to społeczeństwo.

\section{Bibliografia}

\section{Opracowania}

Bafia, Jerzy. Mioduski, Kryspin. Siewierski, Mieczysław. Kodeks karny. Komentarz, (Warszawa: Wydawnictwo Prawnicze, 1987).

Dajnowicz-Piesiecka, Diana. Przestępczość godzaca w rodzinę. Studium prawno-kryminologiczne, (Białystok: Temida2, 2020).

Doniec, Renata. „Oblicza codzienności a kondycja psychospołeczna rodziny w czasach socjalizmu realnego w Polsce”, w: Barbara Kiereś, Monika Gromek, Katarzyna Hryszan (red.), Rodzina - historia i współczesność, (Lublin: Wydawnictwo Episteme, 2018).

Fiedorczyk, Piotr. Unifikacja i kodyfikacja prawa rodzinnego $w$ Polsce (1945-1964), (Białystok: Wydawnictwo Uniwersytetu w Białymstoku, 2014).

Garlicki, Leszek. „Komentarz do art. 18 Konstytucji RP”, w: Leszek Garlicki, Marek Zubik (red.), Konstytucja Rzeczypospolitej Polskiej. Komentarz, t. 1, (Warszawa: Wydawnictwo Sejmowe, 2016), baza prawnicza LEX.

Łopatka, Adam. „Ogólne założenia polityki legislacyjnej PRL”, Państwo i Prawo, z. 1(311), 1972.

Makiłła, Dariusz. Historia prawa $w$ Polsce, (Warszawa: Wydawnictwo Naukowe PWN, 2008).

Murzynowski, Andrzej. „Nałożenie obowiązu naprawienia skutków przestępstwa jako element nowej polityki karania", Państwo i Prawo, nr 5, 1970. 
Radwański, Zbigniew. „Zmiany konstytucyjne PRL dotyczące rodziny”, Ruch Prawniczy, Ekonomiczny i Socjologiczny, z. 2, 1977.

\section{Akty prawne i orzecznictwo}

Konstytucja Polskiej Rzeczypospolitej Ludowej uchwalona przez Sejm Ustawodawczy w dniu 22 lipca 1952 r., (t.j. Dz.U. z 1976 r. $\mathrm{Nr}$ 7, poz. 36 ze zmianami wniesionymi do 30 grudnia 1989 r.).

Konstytucja Polskiej Rzeczypospolitej Ludowej uchwalona przez Sejm Ustawodawczy w dniu 22 lipca 1952 r., (Dz.U. 1952 r. Nr 33, poz. 232).

Konstytucja Rzeczypospolitej Polskiej z dnia 2 kwietnia 1997 r., (Dz.U. Nr 78, poz. 483 ze zm.).

Międzynarodowy Pakt Praw Gospodarczych, Społecznych i Kulturalnych otwarty do podpisu w Nowym Jorku dnia 19 grudnia 1966 r., (Dz.U. 1977 Nr 38, poz. 169).

Międzynarodowy Pakt Praw Obywatelskich i Politycznych otwarty do podpisu w Nowym Jorku dnia 19 grudnia 1966 r., (Dz.U. $1977 \mathrm{Nr} 38$, poz. 167).

Rozporządzenie Prezydenta Rzeczypospolitej z dnia 11 lipca 1932 r. - Kodeks karny, (Dz.U. z 1932 r. Nr 60, poz. 571).

Uchwała Sadu Najwyższego z dnia 28 maja 1955 r., sygn. I CO 5/55, OSNCK 1955, Nr 3, poz. 46 [online] [dostęp: 8.08.2021]. Dostępna w World Wide Web: https://sip.lex.pl/orzeczenia-i-pisma-urzedowe/orzeczenia-sadow/i-co-5-55-uchwala-sadu-najwyzszego-520211685.

Ustawa $z$ dnia 10 lutego 1976 r. o zmianie Konstytucji Polskiej Rzeczypospolitej Ludowej, (Dz.U. 1976 Nr 5, poz. 29).

Ustawa $z$ dnia 18 lipca 1974 r. o funduszu alimentacyjnym, (Dz.U. $1974 \mathrm{Nr} 27$, poz. 157).

Ustawa $z$ dnia 19 kwietnia 1969 r. - Kodeks karny, (Dz.U. 1969 r., Nr 13, poz. 94).

Ustawa z dnia 25 lutego 1964 r. - Kodeks rodzinny i opiekuńczy, (Dz.U. 1964 Nr 9, poz. 59).

Ustawa $z$ dnia 27 czerwca 1950 r. - Kodeks rodzinny, (Dz.U. 1950 $\mathrm{Nr} 34$, poz. 308).

Akty prawne dostępne sa online: https://isap.sejm.gov.pl/isap. nsf/home.xsp. 